\title{
Recent progress in sulfide-based solid electrolytes for Li-ion batteries
}

D. Liu*, W. Zhu, Z. Feng, A. Guerfi, A. Vijh, and K. Zaghib

(C) 2016. This manuscript version is made available under the Elsevier user license http://www.elsevier.com/open-access/userlicense/1.0/ 


\begin{abstract}
Sulfide-based ionic conductors are one of most attractive solid electrolyte candidates for allsolid-state batteries. In this review, recent progress of sulfide-based solid electrolytes is described from point of view of structure. In particular, lithium thio-phosphates such as $\mathrm{Li}_{7} \mathrm{P}_{3} \mathrm{~S}_{11}$, $\mathrm{Li}_{10} \mathrm{GeP}_{2} \mathrm{~S}_{12}$ and $\mathrm{Li}_{11} \mathrm{Si}_{2} \mathrm{PS}_{12}$ et al exhibit extremely high ionic conductivity of over $10^{-2} \mathrm{~S} \mathrm{~cm}^{-1}$ at room temperature, even higher than those of commercial organic carbonate electrolytes. The relationship between structure and unprecedented high ionic conductivity is delineated; some potential drawbacks of these electrolytes are also outlined.
\end{abstract}

Keywords: sulfide, solid-steate electrolyte, Li-ion batteries 


\section{Introduction}

Power/energy densities are critical parameters for developing next generation Li-ion batteries for hybrid electric vehicle (HEV) and plug-in hybrid electric vehicle (PHEV) applications. High energy density can be achieved either by high voltage or high capacity [1-2]. Currently, state-ofthe-art Li-ion batteries utilize organic liquid electrolytes consisting of $\mathrm{LiPF}_{6}$ dissolved in flammable alkyl carbonates. The operating voltages of some high-voltage cathode electrodes, such as $\mathrm{LiMn}_{1.5} \mathrm{Ni}_{0.5} \mathrm{O}_{4}$ and $\mathrm{LiCoPO}_{4}$, are beyond the voltage stability window of the aforementioned electrolyte [3]. Thus, the electrolyte undergoes continuous oxidative decomposition during cycling. In addition, overcharging of the battery may lead to a decomposition of the solid electrolyte interface (SEI) and to chemical reactions between electrolyte and electrode materials. The resulting temperature increase may then cause melting of the separator and finally burning of the battery [4]. Therefore, safety issues become immense concern in developing advanced energy storage technologies, especially for Li-ion batteries. In the past two decades, all-solid-state rechargeable lithium batteries have attracted more and more attention because the replacement of an organic liquid electrolyte with a safer and more reliable inorganic solid electrolyte simplifies the battery design and improves safety and durability of the battery [5-6].

Solid electrolytes need to have high ionic conductivity at room temperature and low activation energy $\left(E_{\mathrm{a}}\right)$ for use over a broad range of operating temperatures. Lithium nitride $\left(\mathrm{Li}_{3} \mathrm{~N}\right)$ was firstly discovered in the 1970s [7] with high ionic conductivity of $6 \times 10^{-3} \mathrm{~S} \mathrm{~cm}^{-1}$ at room temperature as a potential solid electrolyte [8]. Unfortunately, its low electrochemical decomposition potential prevents it being used in practical applications. In addition, other properties such as electrochemical stability against the anode and cathode, and environmental stability are also preferred for solid electrolytes as they reduce the complexity of the battery. 
Studies in the past decades have mainly focused on ionically conducting oxides and sulfides such as NASICON ( $\mathrm{Na}$ Super Ionic Conductor)-type $\mathrm{Li}_{1.3} \mathrm{Al}_{0.3} \mathrm{Ti}_{1.7}\left(\mathrm{PO}_{4}\right)_{3}$ [9], LISICON (Lithium Super Ionic Conductor)-type $\mathrm{Li}_{14} \mathrm{ZnGe}_{4} \mathrm{O}_{16}$ [10], perovskite $\mathrm{La}_{0.5} \mathrm{Li}_{0.5} \mathrm{TiO}_{3}$ [11], garnet $\mathrm{Li}_{7} \mathrm{La}_{3} \mathrm{Zr}_{2} \mathrm{O}_{12}$ [12] and glass-ceramic $\mathrm{Li}_{2} \mathrm{~S}_{-} \mathrm{P}_{2} \mathrm{~S}_{5}$ [13, 14]. These conductors exhibit ionic conductivities at room temperature of the order of $10^{-3} \mathrm{~S} \mathrm{~cm}^{-1}$ with $E_{\mathrm{a}}$ ranging from 0.3 to $0.6 \mathrm{eV}$ [15]. Another system currently being investigated as solid electrolyte is amorphous Lipon (Lithium Phosphorus Oxynitride). Although has a relatively lower ionic conductivity of $2 \times 10^{-6} \mathrm{~S}$ $\mathrm{cm}^{-1}$ at $25^{\circ} \mathrm{C}$, a very thin layer $(1 \mu \mathrm{m})$ of Lipon can be used as electrolyte in solid-state batteries to compensate for its low conductivity $[16,17]$. And it has been reported to show excellent cell performance over thousands of cycles at room temperature [18]. However, the limited cell capacity due to low loading of active material and high cost of fabrication are disadvantages of thin-film batteries.

Recently, a series of overviews on inorganic Li-ion conductors have been published by Quartarone [19], Knauth [15], Goodenough [20] and Kim [21] et al. Moreover, Anantharamulu et al [22] summarized the comprehensive information of NASICON-type compositions; the recent developments in garnet solid electrolytes were reviewed by Teng et al [23]; meanwhile, Thangadurai et al [24] also compared the garnet-type solid-state Li-ion conductors for lithium batteries; the development of sulfide solid electrolytes was reported from the viewpoint of processing and fabrication of all-solid-state lithium batteries by Berbano [25] and Tatsumisago [26], respectively. In present work, we review the recent progress of the sulfide-based solid electrolytes for lithium batteries. But unlike ref. [25] and [26], we mainly focus on the sulfidebased solid electrolytes from a structural point of view. Especially, the structural developments of $\mathrm{Li}_{2} \mathrm{~S}-\mathrm{P}_{2} \mathrm{~S}_{5}$ glass and glass-ceramic are firstly reviewed. Meanwhile, many additives such as $\mathrm{M}_{x} \mathrm{~S}_{y}$ $\left(\mathrm{M}=\mathrm{Sn}, \mathrm{Ge}, \mathrm{Si}, \mathrm{Bi}\right.$ et al) and $\mathrm{Li}_{a} \mathrm{X}_{b}(\mathrm{X}=\mathrm{Cl}, \mathrm{Br}, \mathrm{I}, \mathrm{O}$ et al) have been used to increase the ionic 
conductivity of sulfide-based solid-state electrolyte. Therefore, the structural change and ionic conductivity of $\mathrm{Li}_{2} \mathrm{~S}-\mathrm{M}_{x} \mathrm{~S}_{y}-\mathrm{P}_{2} \mathrm{~S}_{5}$ solid solution and $\mathrm{Li}_{2} \mathrm{~S}-\mathrm{P}_{2} \mathrm{~S}_{5}-\mathrm{Li}_{a} \mathrm{X}_{b}$ system are also discussed separately in this work.

\section{Development of sulfide-based solid electrolytes}

Material design of crystalline ionic conductors is based on certain structural criteria [5, 27-28]: (1) mobile ions should have a suitable size for conduction pathways in the lattice, (2) there should be disorder in a mobile ion sublattice, and (3) highly polarizable mobile ions and anion sublattices are preferable. Since the radius of $\mathrm{S}^{2-}$ is larger than $\mathrm{O}^{2-}$, substitution of $\mathrm{O}^{2-}$ by $\mathrm{S}^{2-}$ can significantly enlarge the size of $\mathrm{Li}^{+}$transport bottlenecks. In addition, $\mathrm{S}^{2-}$ has better polarization capability than $\mathrm{O}^{2-}$, thus weakens the interaction between skeleton and $\mathrm{Li}^{+}$ions. Therefore, a series of sulfide compounds have been explored and exhibited high ionic conductivity (over $10^{-5} \mathrm{~S} \mathrm{~cm}^{-1}$ ) at room temperature. For example, Fig. 1 shows the different $\mathrm{Li}_{2} \mathrm{~S}-\mathrm{GeS}-\mathrm{P}_{2} \mathrm{~S}_{5}$ ternary system compounds as Li-ion conductors and the corresponding conductivities are summarized in Table 1.

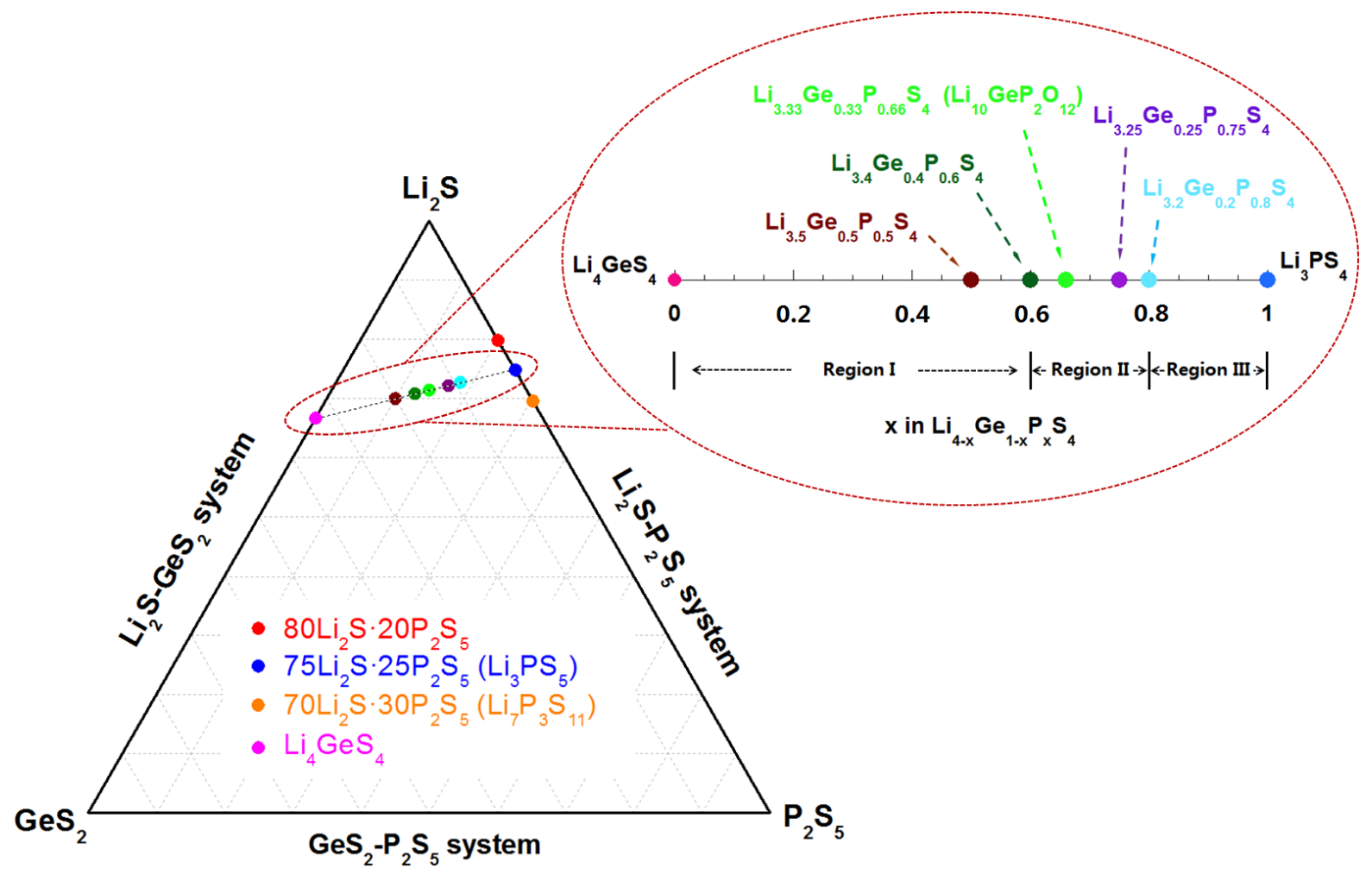


Fig. 1. $\mathrm{Li}_{2} \mathrm{~S}-\mathrm{GeS}_{2}-\mathrm{P}_{2} \mathrm{~S}_{5}$ ternary diagram showing various sulphide compounds as solid electrolytes for Li-ion batteries.

Table 1. Conductivities of different sulfide compounds at $25^{\circ} \mathrm{C}$.

\begin{tabular}{|c|c|c|c|}
\hline Composition & $\begin{array}{l}\text { Conductivity at } 25^{\circ} \mathrm{C} \\
\left(\mathrm{S} \mathrm{cm}^{-1}\right)\end{array}$ & Classification & Reference \\
\hline $2 \mathrm{Li}_{2} \mathrm{~S} \cdot \mathrm{P}_{2} \mathrm{~S}_{5}$ & $1.0 \times 10^{-4}$ & Glass & [29] \\
\hline $70 \mathrm{Li}_{2} \mathrm{~S} \cdot 30 \mathrm{P}_{2} \mathrm{~S}_{5}$ & $5.4 \times 10^{-5}$ & Glass & {$[14]$} \\
\hline $75 \mathrm{Li}_{2} \mathrm{~S} \cdot 25 \mathrm{P}_{2} \mathrm{~S}_{5}$ & $2.0 \times 10^{-4}$ & Glass & {$[32]$} \\
\hline $70 \mathrm{Li}_{2} \mathrm{~S} \cdot 30 \mathrm{P}_{2} \mathrm{~S}_{5}$ & $3.2 \times 10^{-3}$ & Glass-ceramic & [14] \\
\hline $80 \mathrm{Li}_{2} \mathrm{~S} \cdot 20 \mathrm{P}_{2} \mathrm{~S}_{5}$ & $7.4 \times 10^{-4}$ & Glass-ceramic & {$[32]$} \\
\hline $\mathrm{Li}_{7} \mathrm{P}_{3} \mathrm{~S}_{11-\mathrm{z}}$ & $5.4 \times 10^{-3}$ & Glass-ceramic & {$[30]$} \\
\hline $\mathrm{Li}_{7} \mathrm{P}_{3} \mathrm{~S}_{11}$ & $1.7 \times 10^{-2}$ & Glass-ceramic & {$[33]$} \\
\hline $\mathrm{Li}_{3.25} \mathrm{P}_{0.95} \mathrm{~S}_{4}$ & $1.3 \times 10^{-3}$ & Glass-ceramic & {$[34]$} \\
\hline$\gamma-\mathrm{Li}_{3} \mathrm{PS}_{4}$ & $3.0 \times 10^{-7}$ & Crystalline & {$[35]$} \\
\hline$\beta-\mathrm{Li}_{3} \mathrm{PS}_{4}$ & $1.6 \times 10^{-4}$ & Crystalline & {$[36]$} \\
\hline $\mathrm{Li}_{3.25} \mathrm{Ge}_{0.25} \mathrm{P}_{0.75} \mathrm{~S}_{4}$ & $2.2 \times 10^{-3}$ & Crystalline & {$[27]$} \\
\hline $\mathrm{Li}_{10} \mathrm{GeP}_{2} \mathrm{~S}_{12}$ & $1.2 \times 10^{-2}$ & Crystalline & {$[40]$} \\
\hline $\mathrm{Li}_{10} \mathrm{SnP}_{2} \mathrm{~S}_{12}$ & $4.0 \times 10^{-3}$ & Crystalline & {$[43]$} \\
\hline $\mathrm{Li}_{11} \mathrm{Si}_{2} \mathrm{PS}_{12}$ & $>1.2 \times 10^{-2}$ & Crystalline & {$[44]$} \\
\hline $80\left(0.7 \mathrm{Li}_{2} \mathrm{~S} \cdot 0.3 \mathrm{P}_{2} \mathrm{~S}_{5}\right) \cdot 20 \mathrm{LiI}$ & $5.6 \times 10^{-4}$ & Glass & {$[48]$} \\
\hline $95\left(0.8 \mathrm{Li}_{2} \mathrm{~S} \cdot 0.2 \mathrm{P}_{2} \mathrm{~S}_{5}\right) \cdot 5 \mathrm{LiI}$ & $2.7 \times 10^{-3}$ & Glass & {$[49]$} \\
\hline $\mathrm{Li}_{7} \mathrm{P}_{2} \mathrm{~S}_{8} \mathrm{I}$ & $6.3 \times 10^{-4}$ & Crystalline & {$[50]$} \\
\hline
\end{tabular}




\begin{tabular}{|l|l|l|l|}
\hline $56 \mathrm{Li}_{2} \mathrm{~S} \cdot 24 \mathrm{P}_{2} \mathrm{~S}_{5} \cdot 20 \mathrm{Li}_{2} \mathrm{O}$ & $>1.0 \times 10^{-4}$ & Glass & {$[52]$} \\
$75 \mathrm{Li}_{2} \mathrm{~S} \cdot 21 \mathrm{P}_{2} \mathrm{~S}_{5} \cdot 4 \mathrm{P}_{2} \mathrm{O}_{5}$ & $>1.0 \times 10^{-4}$ & Glass & {$[53]$} \\
$67.5 \mathrm{Li}_{2} \mathrm{~S} \cdot 7.5 \mathrm{Li}_{2} \mathrm{O} \cdot 25 \mathrm{P}_{2} \mathrm{~S}_{5}$ & $1.1 \times 10^{-4}$ & Glass & {$[54]$} \\
$0.33\left(0.7 \mathrm{~B}_{2} \mathrm{~S}_{3} \cdot 0.3 \mathrm{P}_{2} \mathrm{~S}_{5}\right)-0.67 \mathrm{~L}_{2} \mathrm{~S}$ & $1.4 \times 10^{-4}$ & Glass & {$[57]$} \\
$67\left(0.75 \mathrm{Li}_{2} \mathrm{~S} \cdot 0.25 \mathrm{P}_{2} \mathrm{~S}_{5}\right) \cdot 33 \mathrm{LiBH}_{4}$ & $1.6 \times 10^{-3}$ & Glass & {$[58]$} \\
\hline
\end{tabular}

\section{3. $\mathrm{Li}_{2} \mathrm{~S}-\mathrm{P}_{2} \mathrm{~S}_{5}$ glass and glass-ceramic}

Sulfite glasses in the systems $\mathrm{Li}_{2} \mathrm{~S}-\mathrm{P}_{2} \mathrm{~S}_{5}$ and $\mathrm{Li}_{2} \mathrm{~S}-\mathrm{SiS}_{2}$, prepared by the melt-quenching method, are known to be Li-ion conductors with conductivities over $10^{-4} \mathrm{~S} \mathrm{~cm}^{-1}$ at room temperature [29, 31]. For instance, in the binary system of $\mathrm{Li}_{2} \mathrm{~S}_{-} \mathrm{P}_{2} \mathrm{~S}_{5}$, perfect amorphous with no crystalline structure were obtained up to the $\mathrm{Li}_{2} \mathrm{~S}$ contents of $75 \mathrm{~mol} \%$, and the maximum conductivity of the glassy powders was about $2 \times 10^{-4} \mathrm{~S} \mathrm{~cm}^{-1}$ at $25{ }^{\circ} \mathrm{C}$ in the case of $75 \mathrm{Li}_{2} \mathrm{~S} \cdot 25 \mathrm{P}_{2} \mathrm{~S}_{5}$ [32]. In order to improve the conductivity of glassy electrolytes, several approaches have been proposed. One effective way is to simply crystallize the glass precursors. Precipitation of thermodynamically stable $\mathrm{Li}_{2} \mathrm{~S}_{-} \mathrm{P}_{2} \mathrm{~S}_{5}$ glass electrolytes produces glass-ceramic (crystallized glass) electrolytes. However, different results have been reported for the correlation between conductivity and crystallization. For instance, Minami et al suggested [37] that the $\mathrm{Cu}^{+}$ion conducting glasses exhibited higher ionic conductivity than crystals since glasses have larger free volume than crystals because of their random and open structure. Whereas Pietrzak et al [38] showed significant increase in electronic conductivity of nanocrystallized $\mathrm{V}_{2} \mathrm{O}_{5}-\mathrm{P}_{2} \mathrm{O}_{5}$ glasses. While in the $\mathrm{Li}_{2} \mathrm{~S}-\mathrm{P}_{2} \mathrm{~S}_{5}$ system, ionic conductivity was reported to depend on the temperature range $[14$, 32]. Fig. 2 shows the $\mathrm{X}$-ray diffraction (XRD) patterns of the pristine $80 \mathrm{Li}_{2} \mathrm{~S} \cdot 20 \mathrm{P}_{2} \mathrm{~S}_{5}$ glass and the samples after heating at different temperatures. As can be seen from Fig. 2, several new 
diffraction peaks were observed after heat treatment up to $500{ }^{\circ} \mathrm{C}$. And the highest conductivity of $7.4 \times 10^{-4} \mathrm{~S} \mathrm{~cm}^{-1}$ was obtained when the temperature was around $210-230{ }^{\circ} \mathrm{C}$. Tatsumisago [32] assumed that the $\mathrm{Li}$-richer $\mathrm{Li}_{3+5 y} \mathrm{P}_{1-\mathrm{y}} \mathrm{S}_{4}$ phases, where $\mathrm{Li}_{3} \mathrm{PS}_{4}\left(=75 \mathrm{Li}_{2} \mathrm{~S} \cdot 25 \mathrm{P}_{2} \mathrm{~S}_{5}\right)$ phase was lacking in phosphorus, were formed in the $\mathrm{Li}_{2} \mathrm{~S}-\mathrm{P}_{2} \mathrm{~S}_{5}$ glass-ceramics. The crystal structures of $\mathrm{Li}_{3.25} \mathrm{P}_{0.95} \mathrm{~S}_{4}$ and $\mathrm{Li}_{3.2} \mathrm{P}_{0.96} \mathrm{~S}_{4}$ would be similar to those of $\mathrm{Li}_{3.25} \mathrm{Ge}_{0.25} \mathrm{P}_{0.75} \mathrm{~S}_{4}$ (thio-LISICON Li $\mathrm{S}_{2}-\mathrm{GeS}_{2}-\mathrm{P}_{2} \mathrm{~S}_{5}$ Region II in Fig. 1) and $\mathrm{Li}_{3.2} \mathrm{Ge}_{0.2} \mathrm{P}_{0.8} \mathrm{~S}_{4}$ (thio-LISICON $\mathrm{Li}_{2} \mathrm{~S}-\mathrm{GeS}_{2}-\mathrm{P}_{2} \mathrm{~S}_{5}$ Region III in Fig. 1), respectively. The heat treatment at $240{ }^{\circ} \mathrm{C}$ brought about the precipitation of the most conductive thio-LISICON region II analogs such as $\mathrm{Li}_{3.25} \mathrm{P}_{0.95} \mathrm{~S}_{4}$. Therefore, the conductivity enhancement by the heat treatment was due to the formation of the highly conductive thio-LISICON region II phase.

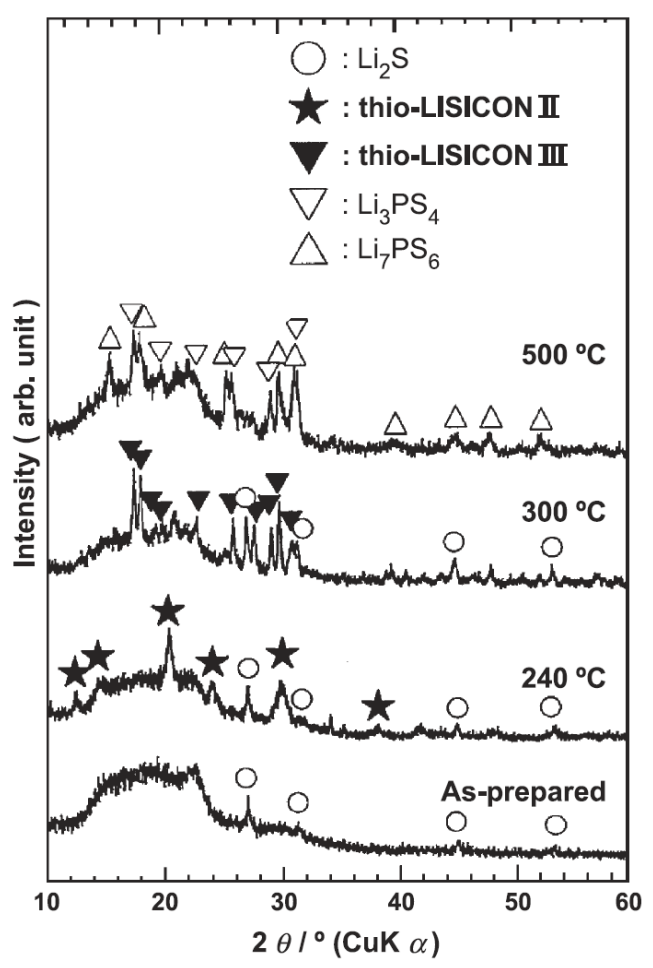

Fig. 2. X-ray diffraction patterns of the $80 \mathrm{Li}_{2} \mathrm{~S} \cdot 20 \mathrm{P}_{2} \mathrm{~S}_{5}$ glass and the samples after heating the glass at different temperatures [32]. 


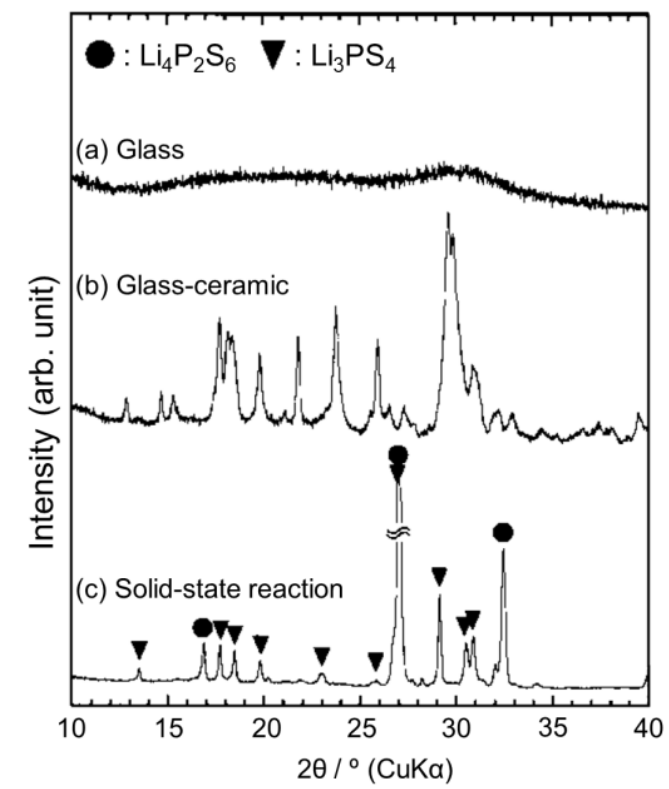

Fig. 3. X-ray diffraction patterns of (a) the $70 \mathrm{Li}_{2} \mathrm{~S} \cdot 30 \mathrm{P}_{2} \mathrm{~S}_{5}$ glass, (b) the glass-ceramic, and (c) the sample obtained from the solid-state reaction [14].

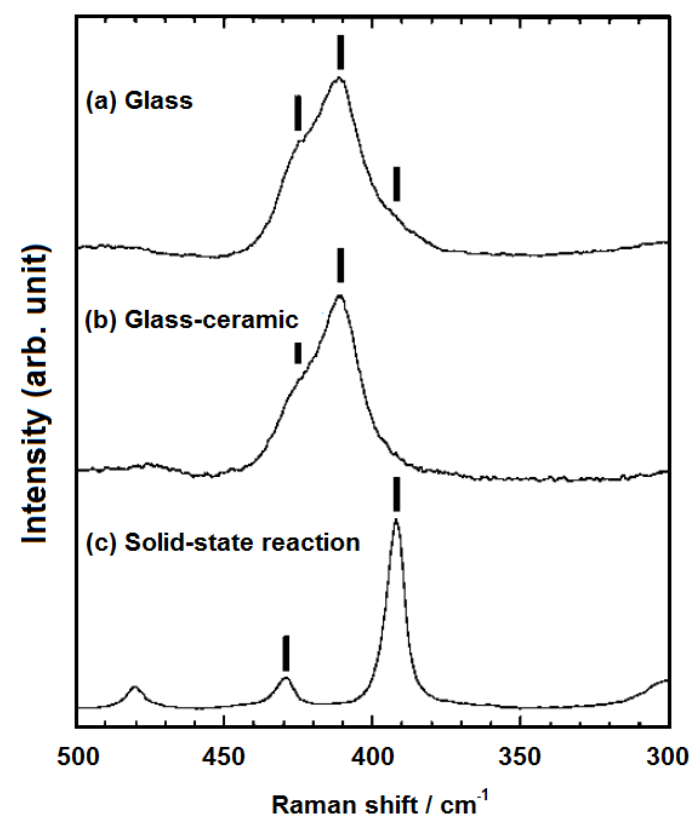

Fig. 4. Raman spectra of (a) the $70 \mathrm{Li}_{2} \mathrm{~S} \cdot 30 \mathrm{P}_{2} \mathrm{~S}_{5}$ glass, (b) the glass-ceramic , and (c) the sample obtained from the solid-state reaction [14]. 
Similarly, Mizuno et al [14] also found that after a heat treatment of the mechanically milled glass at $240{ }^{\circ} \mathrm{C}$ for $2 \mathrm{~h}$, a new crystalline phase, which was different from either the pristine glass or the sample obtained by solid-state reaction (as shown in Fig. 3), was formed in the $70 \mathrm{Li}_{2} \mathrm{~S} \cdot 30 \mathrm{P}_{2} \mathrm{~S}_{5}$ glass-ceramics. However, local structural analysis of Raman spectroscopy in Fig. 4 revealed that the new crystal was mainly composed of $\mathrm{P}_{2} \mathrm{~S}_{7}{ }^{4-}$ (pyro-thiophosphate) ions (410 $\mathrm{cm}^{-1}$ ) in the glass-ceramic, which is different from that of thio-LISICONs. In spite of lesser Liion content, the $70 \mathrm{Li}_{2} \mathrm{~S} \cdot 30 \mathrm{P}_{2} \mathrm{~S}_{5}$ glass-ceramic showed a higher conductivity of $3.2 \times 10^{-3} \mathrm{~S} \mathrm{~cm}^{-1}$ than $80 \mathrm{Li}_{2} \mathrm{~S} \cdot 20 \mathrm{P}_{2} \mathrm{~S}_{5}$ glass-ceramic. Mizuno et al thus suggested that the new phase was more conductive than thio-LISICONs. Moreover, the authors also suggested the conducting properties of $\mathrm{Li}_{2} \mathrm{~S}-\mathrm{P}_{2} \mathrm{~S}_{5}$ glass-ceramics largely depended on the precipitated crystalline phases, which were controlled by the compositions and heat treatment conditions of the mother glasses [34]. Highly ion-conductive crystals such as the new crystal in the $70 \mathrm{Li}_{2} \mathrm{~S} \cdot 30 \mathrm{P}_{2} \mathrm{~S}_{5}$ glass-ceramics changed into thermodynamically stable phase with increases in heat treatment temperatures, resulting in low conductivity of the glass-ceramics, as compared in Fig. 5. 


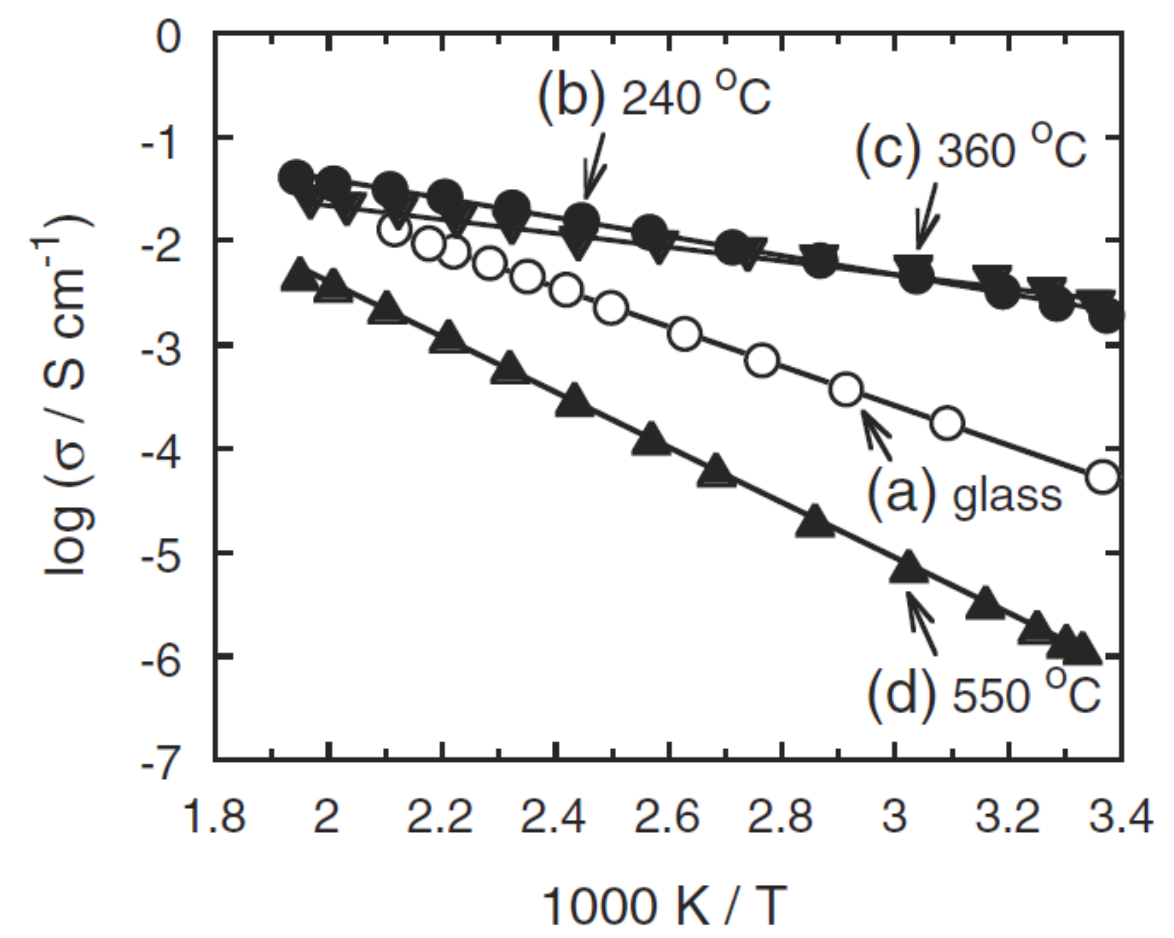

Fig. 5. Temperature dependences of the conductivities for the $70 \mathrm{Li}_{2} \mathrm{~S} \cdot 30 \mathrm{P}_{2} \mathrm{~S}_{5}(\mathrm{~mol} \%)$ glassceramics obtained by heating the pelletized glasses up to various temperatures; the heat treatment temperatures are (a) as-prepared, (b) $240{ }^{\circ} \mathrm{C}$, (c) $360^{\circ} \mathrm{C}$ and (d) $550{ }^{\circ} \mathrm{C}$ [34].

Tatsumisago [26] further proved that the new phase by heating the $70 \mathrm{Li}_{2} \mathrm{~S} \cdot 30 \mathrm{P}_{2} \mathrm{~S}_{5}$ glass at $240{ }^{\circ} \mathrm{C}$ was $\mathrm{Li}_{7} \mathrm{P}_{3} \mathrm{~S}_{11}$ and the crystallinity of $\mathrm{Li}_{7} \mathrm{P}_{3} \mathrm{~S}_{11}$ increased by heating at $360{ }^{\circ} \mathrm{C}$. After heating at $550{ }^{\circ} \mathrm{C}, \mathrm{Li}_{7} \mathrm{P}_{3} \mathrm{~S}_{11}$ phase completely disappeared and thermodynamically stable phases such as $\mathrm{Li}_{4} \mathrm{P}_{2} \mathrm{~S}_{6}$ appeared. This is consistent to the results in ref [14], [32] and [34]. Therefore, the conductivity increased by heating the $70 \mathrm{Li}_{2} \mathrm{~S} \cdot 30 \mathrm{P}_{2} \mathrm{~S}_{5}$ glass at $240{ }^{\circ} \mathrm{C}$ or $360{ }^{\circ} \mathrm{C}$, while the conductivity decreased by heating at $550{ }^{\circ} \mathrm{C}$ due to the lower conductivity of $10^{-6} \mathrm{~S} \mathrm{~cm}^{-1}$ of the $\mathrm{Li}_{4} \mathrm{P}_{2} \mathrm{~S}_{6}$ phase [26]. Fig. 6 shows the structural model of superionic $\mathrm{Li}_{7} \mathrm{P}_{3} \mathrm{~S}_{11}$ crystal. The compound crystallizes in a triclinic cell with a space group of $\mathrm{P}-1$. Both $\mathrm{PS}_{4}{ }^{3-}$ tetrahedral and $\mathrm{P}_{2} \mathrm{~S}_{7}{ }^{4-}$ ditetrahedral ions are contained in the structure and $\mathrm{Li}^{+}$ions are situated between them. 
The crystal structure is completely different from other superionic conducting crystals such as $\mathrm{Li}_{3.25} \mathrm{Ge}_{0.25} \mathrm{P}_{0.75} \mathrm{~S}_{4}$ and $\mathrm{Li}_{10} \mathrm{GeP}_{2} \mathrm{~S}_{12}$, which are composed of only tetrahedral ions ( $\mathrm{PS}_{4}{ }^{3-}$ and $\mathrm{GeS}_{4}{ }^{4-}$ ). $\mathrm{Li}-\mathrm{Li}$ correlations (solid blue lines) are illustrated in Fig. 6 and a favorable $\mathrm{Li}^{+}$ conduction path is presumably close to the Li-Li chains [26].

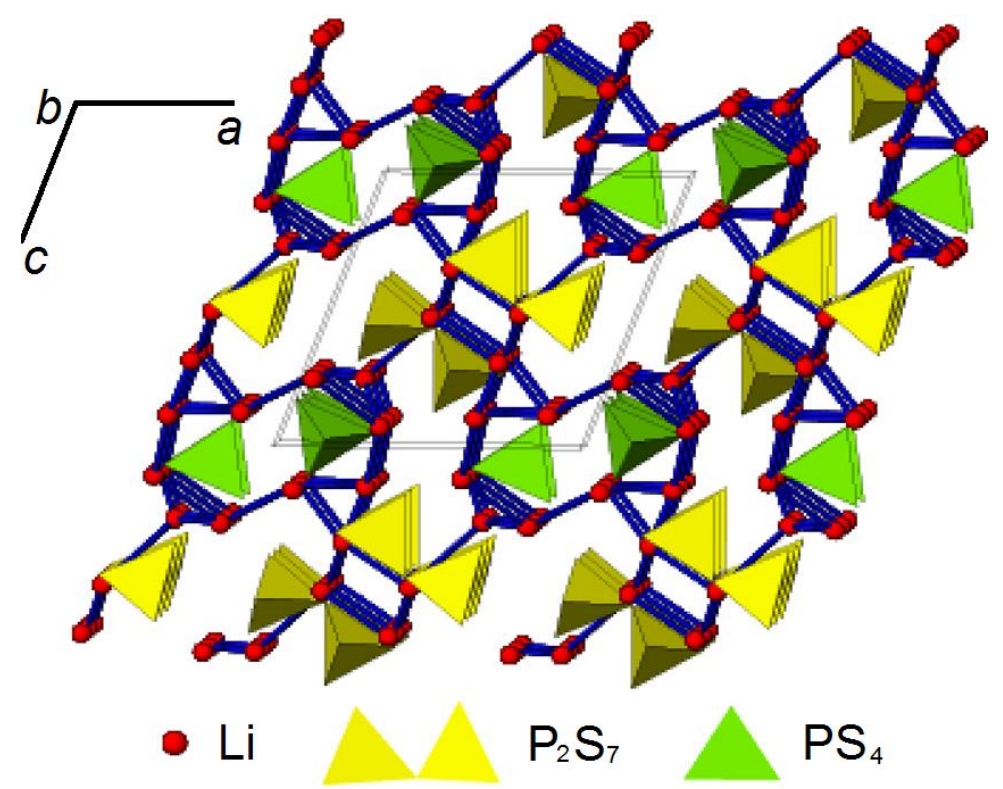

Fig. 6. Structural model of superionic $\mathrm{Li}_{7} \mathrm{P}_{3} \mathrm{~S}_{11}$ crystal [26].

Recently, a $\mathrm{Li}_{7} \mathrm{P}_{3} \mathrm{~S}_{11}$ analogous phase, $\mathrm{Li}_{7} \mathrm{P}_{3} \mathrm{~S}_{11-\mathrm{z}}$, was also reported to have higher conductivity than the $\mathrm{Li}_{7} \mathrm{P}_{3} \mathrm{~S}_{11}$ crystal when substitution of $\mathrm{P}_{2} \mathrm{~S}_{3}$ for $\mathrm{P}_{2} \mathrm{~S}_{5}$ in the $70 \mathrm{Li}_{2} \mathrm{~S} \cdot 30 \mathrm{P}_{2} \mathrm{~S}_{5}$ glass-ceramic. The maximum conductivity of $5.4 \times 10^{-3} \mathrm{~S} \mathrm{~cm}^{-1}$ at room temperature was obtained by using 1 mol\% of $\mathrm{P}_{2} \mathrm{~S}_{3}$ in the $70 \mathrm{Li}_{2} \mathrm{~S} \cdot(30-x) \mathrm{P}_{2} \mathrm{~S}_{5} \cdot x \mathrm{P}_{2} \mathrm{~S}_{3}(\mathrm{~mol} \%)$ glass-ceramic solid electrolyte [30]. Most recently, a densified $70 \mathrm{Li}_{2} \mathrm{~S} \cdot 30 \mathrm{P}_{2} \mathrm{~S}_{5}$ glass-ceramic solid electrolyte was prepared with an aim to increase the ionic conductivity by compressing the glass powders at $94 \mathrm{MPa}$ and then heating at $280{ }^{\circ} \mathrm{C}$ or $300{ }^{\circ} \mathrm{C}$ for $2 \mathrm{~h}$ [33]. After the heat treatment, the glass phase was changed to $\mathrm{Li}_{7} \mathrm{P}_{3} \mathrm{~S}_{11}$ crystal structure and an extremely high ionic conductivity of $1.7 \times 10^{-2} \mathrm{~S} \mathrm{~cm}^{-1}$ at room temperature was observed in the final sulfide solid electrolyte. This is the highest ionic conductivity among 
the Li-ion conductors reported to date, even larger than conventional liquid electrolytes (as compared in Fig. 7). From the scanning electronic microscopy (SEM) images in Fig. 8, it is clear to see that there are still a lot of voids in the cold-pressed glass-ceramic, whereas the individual grains and the grain boundaries are hardly seen in the heat-treated glass-ceramic electrolyte. It suggests that the extremely high ionic conductivity of the unified $70 \mathrm{Li}_{2} \mathrm{~S} \cdot 30 \mathrm{P}_{2} \mathrm{~S}_{5}$ glass-ceramic solid electrolyte was not achieved by enhancing ionic conduction in the bulk, but by its low porosity as well as a decreased grain boundary resistance resulting from heat treatment.

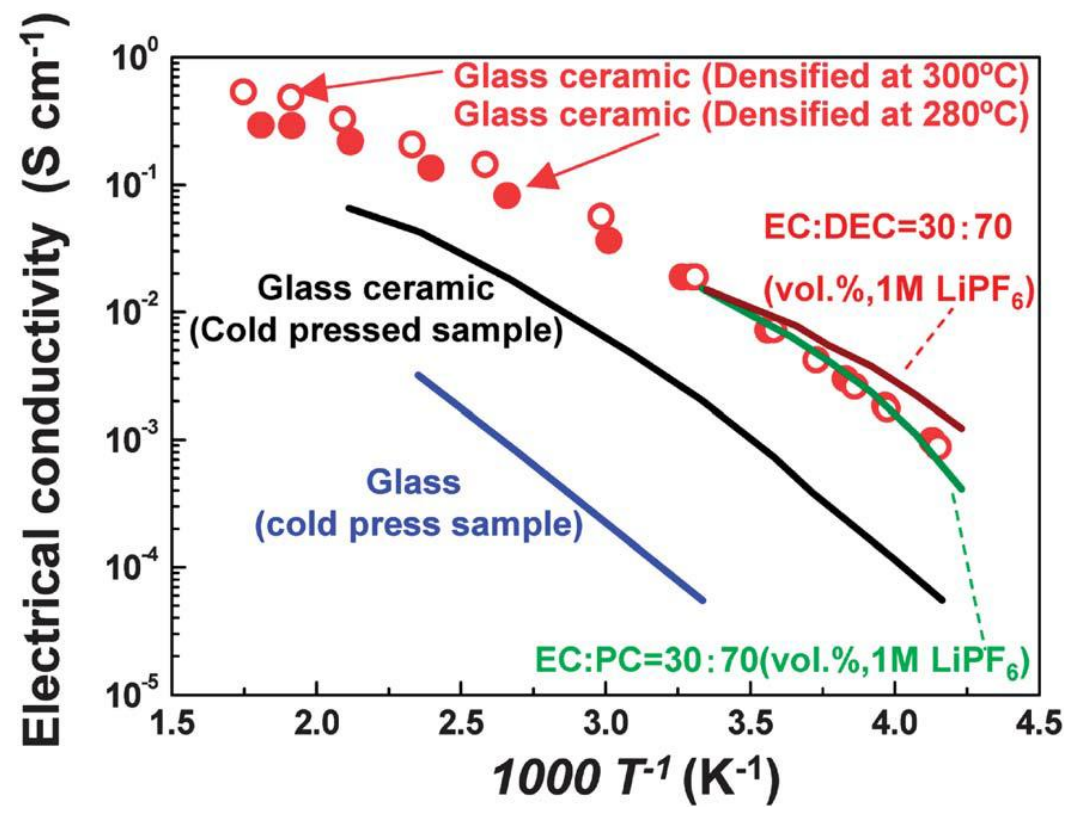

Fig. 7 Temperature dependency of the electrical conductivities of the $70 \mathrm{Li}_{2} \mathrm{~S} \cdot 30 \mathrm{P}_{2} \mathrm{~S}_{5}$ glassceramic samples unified at $280{ }^{\circ} \mathrm{C}$ and $300{ }^{\circ} \mathrm{C}$. The electrical conductivities of the cold-pressed glass, glass-ceramic powders and of some typical liquid electrolytes $\left(1 \mathrm{M} \mathrm{LiPF}_{6}\right.$ in EC-DEC and $1 \mathrm{M} \mathrm{LiPF}_{6}$ in EC-PC) are also shown for comparison purposes [33]. 

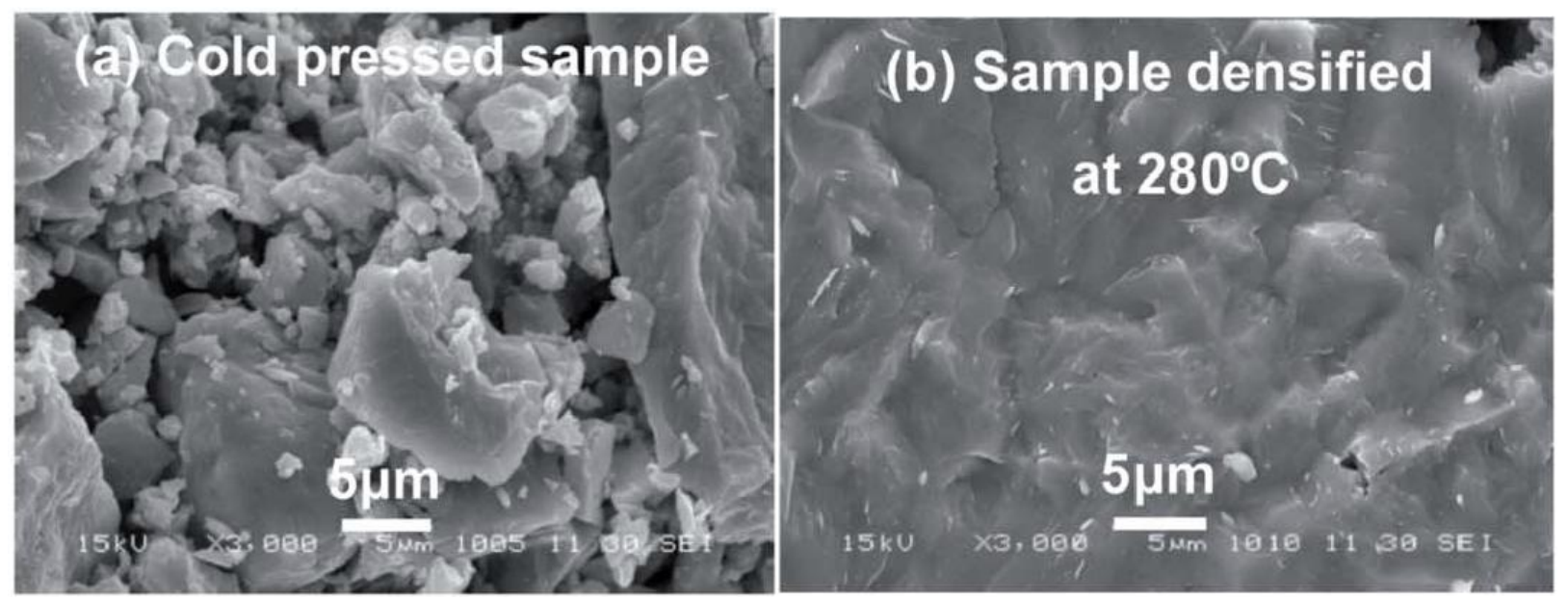

Fig. 8. SEM images of the $70 \mathrm{Li}_{2} \mathrm{~S} \cdot 30 \mathrm{P}_{2} \mathrm{~S}_{5}$ glass-ceramic material from a cold-pressed sample (a) and the heat-treated sample at $280^{\circ} \mathrm{C}[33]$.

\section{Thio-LISICON Li $\mathrm{L}_{2}-\mathrm{M}_{x} \mathrm{~S}_{y}-\mathrm{P}_{2} \mathrm{~S}_{5}$ solid solution}

LISICON $\mathrm{Li}_{14} \mathrm{ZnGe}_{4} \mathrm{O}_{16}$ was first described by Bruce and West as Li-ion conductor [10]. However, $\mathrm{LISICON} \mathrm{Li}_{14} \mathrm{ZnGe}_{4} \mathrm{O}_{16}$ is highly reactive with lithium metal and atmospheric $\mathrm{CO}_{2}$ and the conductivity decreases with time. Therefore, the thio-LISICON families, $\mathrm{Li}_{2} \mathrm{~S}-\mathrm{GeS}_{2}, \mathrm{Li}_{2} \mathrm{~S}$ $\mathrm{GeS}_{2}-\mathrm{ZnS}$ and $\mathrm{Li}_{2} \mathrm{~S}-\mathrm{GeS}_{2}-\mathrm{Ga}_{2} \mathrm{~S}_{3}$, were introduced by Kanno and coworkers to improve the Li ion conductivity [39]. The replacement of oxide ions by larger and more polarizable sulfide in the framework increased ionic mobility. An important characteristic is the wide range of solid solutions obtained by aliovalent substitutions. The ionic conductivity of the orthorhombic parent compound $\mathrm{Li}_{4-2 x} \mathrm{Zn}_{x} \mathrm{GeS}_{4}$ is still quite low $\left(3 \times 10^{-7} \mathrm{~S} \mathrm{~cm}^{-1}\right.$ at room temperature $)$. A significant improvement of ionic conductivity is observed in the $\mathrm{Li}_{2} \mathrm{~S}-\mathrm{GeS}_{2}-\mathrm{Ga}_{2} \mathrm{~S}_{3}$ system: $\mathrm{Li}_{4+x+\delta}\left(\mathrm{Ge}_{1-\delta}\right.$ $\left.{ }_{x} \mathrm{Ga}_{x}\right) \mathrm{S}_{4}$ presents at $x=0.25$ a value as high as $6 \times 10^{-5} \mathrm{~S} \mathrm{~cm}^{-1}$ at ambient temperature. Based on the discovered results, Kanno and Murayama further introduced a new thio-LISICON, $\mathrm{Li}_{4-x} \mathrm{Ge}_{1-x} \mathrm{P}_{x} \mathrm{~S}_{4}$, with the substitution of $\mathrm{Ge}^{4+}+\mathrm{Li}^{+} \leftrightarrow \mathrm{P}^{5+}$ in the $\mathrm{Li}_{2} \mathrm{~S}-\mathrm{GeS}_{2}-\mathrm{P}_{2} \mathrm{~S}_{5}$ system [27]. The structures of the end members, $\mathrm{Li}_{4} \mathrm{GeS}_{4}$ and $\mathrm{Li}_{3} \mathrm{PS}_{4}$, were confirmed by the Rietveld analysis to have similar 
structure to $\gamma-\mathrm{Li}_{3} \mathrm{PO}_{4}$. It was reported that the thio-LISICON $\mathrm{Li}_{4-x} \mathrm{Ge}_{1-x} \mathrm{P}_{x} \mathrm{~S}_{4}$ solid solution can be divided into three composition regions (as illustrated in Fig. 1) from a structural point of view: region I $(0<x \leq 0.6)$, region II $(0.6<x<0.8)$ and region III $(0.8 \leq x<1.0)$. The three regions of the monoclinic superstructures correspond to different types of cation ordering. The thio-LISICON phase in region II has a special monoclinic superstructure and shows much higher conductivities over $10^{-3} \mathrm{~S} \mathrm{~cm}^{-1}$ at room temperature than the other two phases. Compared with the stoichiometric $\mathrm{Li}_{4} \mathrm{GeS}_{4}$, more $\mathrm{Li}^{+}$vacancies were created by aliovalent substitutions in the $\mathrm{Li}_{4-x} \mathrm{Ge}_{1-x} \mathrm{P}_{x} \mathrm{~S}_{4}$ solid solution, thus leading to much higher conductivity.

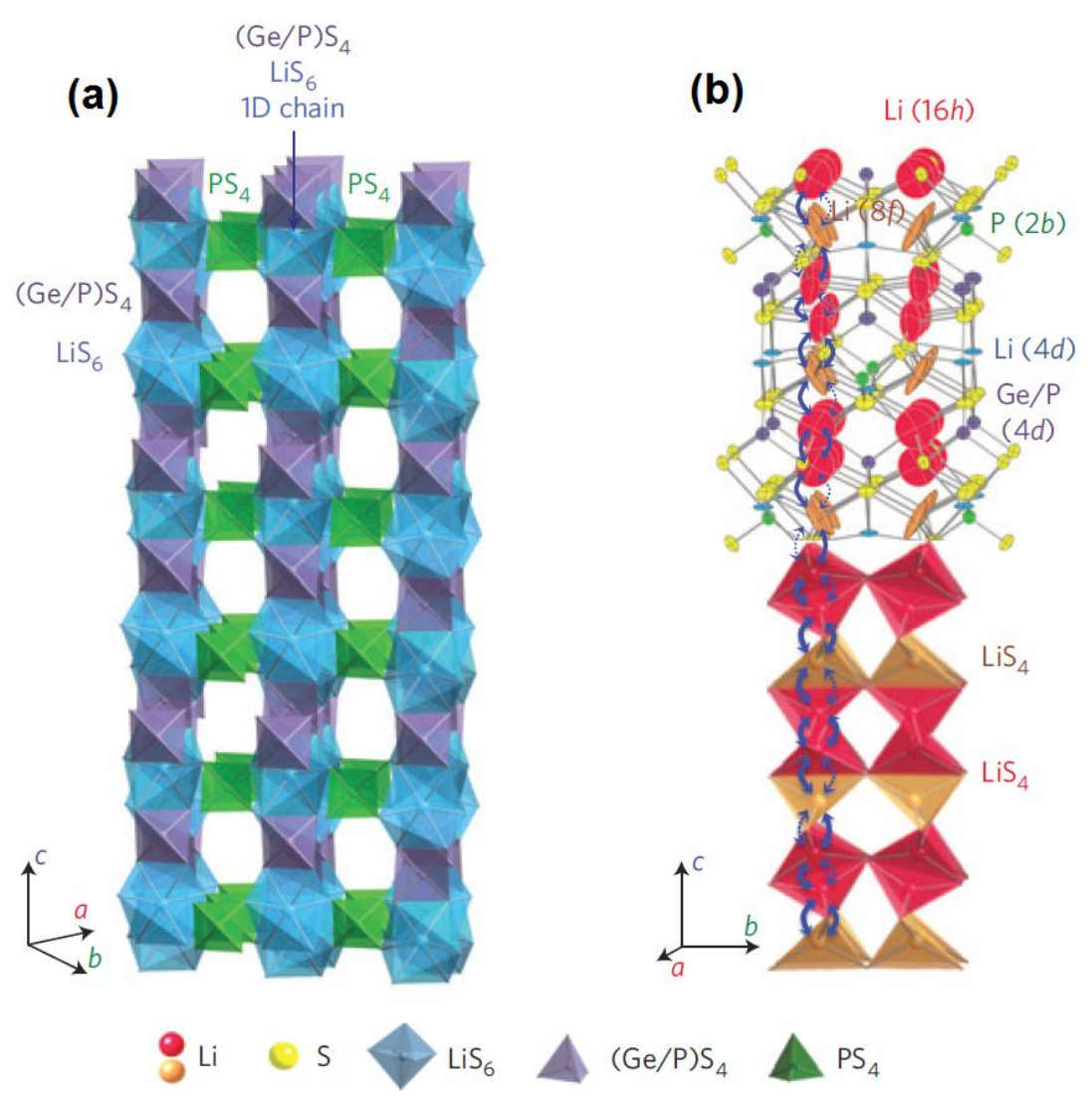

Fig. 9. Framework structure of $\mathrm{Li}_{10} \mathrm{GeP}_{2} \mathrm{~S}_{12}$ (a) and conduction pathways of lithium ions (b). Zigzag conduction pathways along the $c$ axis are indicated. Lithium ions in the $\mathrm{LiS}_{4}$ tetrahedra (16h site) and $\mathrm{LiS}_{4}$ tetrahedra ( $8 f$ site) participate in ionic conduction [40]. 
Recently, a lithium superionic conductor, $\mathrm{Li}_{10} \mathrm{GeP}_{2} \mathrm{~S}_{12}$, was reported to exhibit an extremely high lithium ionic conductivity of $1.2 \times 10^{-2} \mathrm{~S} \mathrm{~cm}^{-1}$ at room temperature, a value comparable to those of the liquid electrolytes used in lithium-ion batteries [40]. $\mathrm{Li}_{10} \mathrm{GeP}_{2} \mathrm{~S}_{12}$, also can be written as $\mathrm{Li}_{3.33} \mathrm{Ge}_{0.33} \mathrm{P}_{0.67} \mathrm{~S}_{4}$, belongs to Region II in the thio-LISICON $\mathrm{Li}_{2} \mathrm{~S}-\mathrm{GeS}_{2}-\mathrm{P}_{2} \mathrm{~S}_{5}$ system in Fig. 1. The crystal structure of $\mathrm{Li}_{10} \mathrm{GeP}_{2} \mathrm{~S}_{12}$ is illustrated in Fig. 9a. The unit cell has two tetrahedral sites: $4 d$ and $2 b$ sites. The $4 d$ tetrahedral site is occupied by Ge and $\mathrm{P}$ ions, while the smaller $2 b$ tetrahedral site is solely occupied by P. There are three lithium sites in the unit cell: $16 h, 4 d$ and $8 f$ sites. The three-dimensional framework is composed of $(\mathrm{Ge} / \mathrm{P}) \mathrm{S}_{4}$ tetrahedra and $\mathrm{LiS}_{6}$ octahedra, which share a common edge and form a 1D chain along the c axis. These 1D chains are connected to one another through $\mathrm{PS}_{4}$ tetrahedra, which are connected to $\mathrm{LiS}_{6}$ octahedra by a common corner. The 1D conduction pathway is formed by $\mathrm{LiS}_{4}$ tetrahedra in the $16 h$ and $8 f$ sites, which share a common edge and form a 1D tetrahedron chain. These chains are connected by common corners of the $\mathrm{LiS}_{4}$ tetrahedra (Fig.9b). Ceder et al [41] predicted that $\mathrm{Li}_{10} \mathrm{GeP}_{2} \mathrm{~S}_{12}$ has a body-centred cubic (bcc) anion sublattice (see in Fig. 10a). In the bcc $\mathrm{S}^{2-}$ lattice, the Li ion migrates with a remarkably low barrier along a path connecting two face-sharing tetrahedral sites (T1 and T2 in Fig. 10b) and bcc is the preferred anion arrangement for Li-ion conductors owing to the low barrier of the T-T path, which is in agreement with the results in ref. [40].
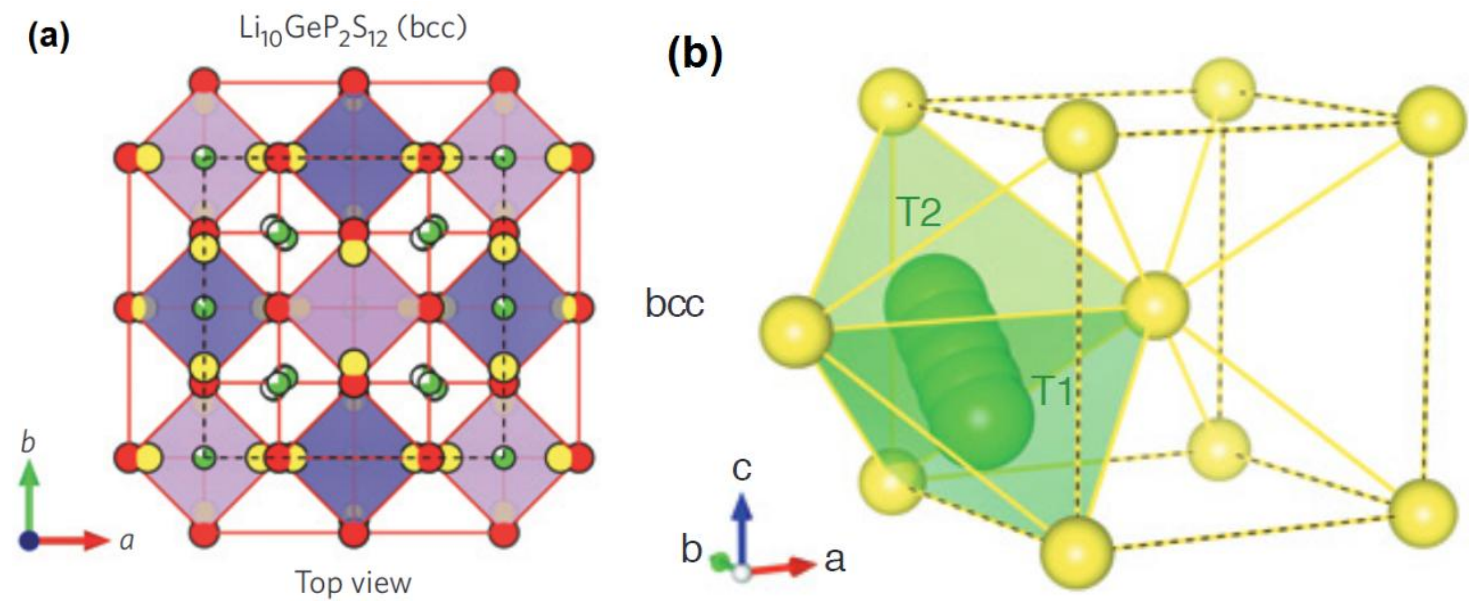
Fig. 10. Body-centred cubic (bcc) anion sublattice of $\mathrm{Li}_{10} \mathrm{GeP}_{2} \mathrm{~S}_{12}$ (a) and Li-ion migration path connected by two face-sharing tetrahedral sites (T1-T2 pathway) [41].

\begin{abstract}
Although an unprecedented high ionic conductivity was obtained in $\mathrm{Li}_{10} \mathrm{GeP}_{2} \mathrm{~S}_{12}$, the Ge atoms in the structure, unfortunately, compromise the chemical compatibility of the lithium thio-phosphate with lithium metal [42]. Another drawback is the high cost of germanium. Therefore, other sulfides, such as $\mathrm{SnS}_{2}$ and $\mathrm{SiS}_{2}$, instead of $\mathrm{GeS}_{2}$ have also been used in the thio-LISICON Li $2 \mathrm{~S}$ $\mathrm{MS}_{2}-\mathrm{P}_{2} \mathrm{~S}_{5}$ solid solution to pursuit ultrafast Li-ion conductors for all-solid-state batteries. As in the $\mathrm{Sn}$ compounds, limited $\mathrm{Sn}$ can be doped in the $\mathrm{Li}_{2} \mathrm{~S}-\mathrm{SnS}_{2}-\mathrm{P}_{2} \mathrm{~S}_{5}$ solid solution with the end member of $\mathrm{Li}_{10} \mathrm{SnP}_{2} \mathrm{~S}_{12}$ [43]. For higher $\mathrm{Sn} / \mathrm{P}$ ratio, impurity phases were obtained. While in the $\mathrm{Li}_{2} \mathrm{~S}-\mathrm{SiS}_{2}-\mathrm{P}_{2} \mathrm{~S}_{5}$ solid solution, more of $\mathrm{P}^{5+}$ can be substituted by $\mathrm{Si}^{4+}$, leading to the end member of $\mathrm{Li}_{11} \mathrm{Si}_{2} \mathrm{PS}_{12}$ [44]. Kuhn et al explained that $\mathrm{Sn}^{4+}, \mathrm{Ge}^{4+}$ and $\mathrm{Si}^{4+}$ share the $4 d$ tetrahedral sites with $\mathrm{P}^{5+}$ ions. Higher occupancy of this position is energetically unfavourable. However, some of the $\mathrm{Si}^{4+}$ ions can occupy the smaller $2 b$ tetrahedral sites (see in Fig. 11a) due to the relatively smaller ionic radius of $\mathrm{Si}^{4+}$. Therefore, higher Li concentration of $\mathrm{Li}_{11} \mathrm{Si}_{2} \mathrm{PS}_{12}$ was successfully obtained by $\mathrm{Li}$ ions charge-compensation $\left(\mathrm{P}^{5+} \leftrightarrow \mathrm{Ge}^{4+}+\mathrm{Li}^{+}\right)$, resulting in lower activation energy and higher Li-ion conductivity (Fig. 11b). Ong et al [45] also proved that the substitution of $\mathrm{Si}$ (an element closer to $\mathrm{P}$ in the periodic table) for $\mathrm{Ge}$ in $\mathrm{Li}_{10} \mathrm{GeP}_{2} \mathrm{~S}_{12}$ lowered its activation energy by $0.01 \mathrm{eV}$, and replacing Ge with $\mathrm{Sn}$ (less similar to P) increased it by $0.03 \mathrm{eV}$.
\end{abstract}




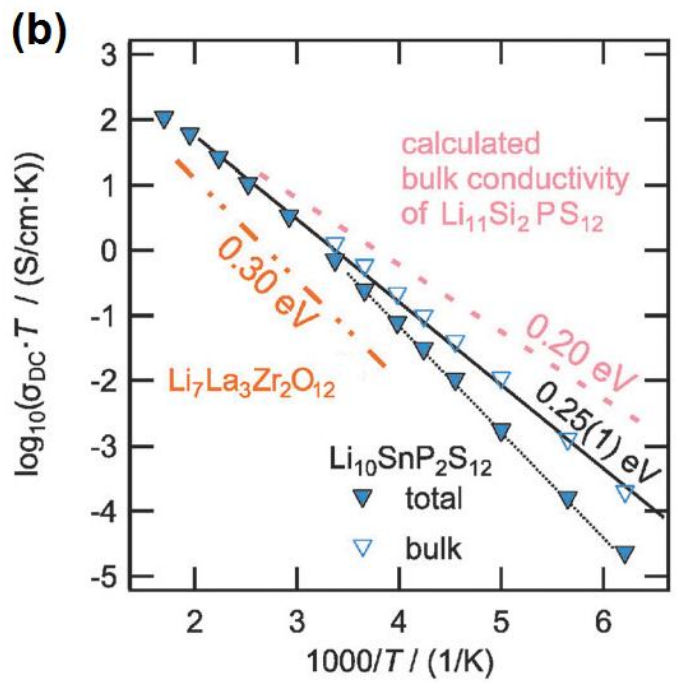

Fig. 11. (a) ${ }^{31} \mathrm{P}$ MAS NMR spectra $\left(v_{\text {rot }}=12 \mathrm{kHz}, B_{\mathrm{o}}=9.4 \mathrm{~T}\right)$ of the different isostructural materials crystallizing in the tetragonal $\mathrm{Li}_{2} \mathrm{~S}-\mathrm{MS}_{2}-\mathrm{P}_{2} \mathrm{~S}_{5}\left(\mathrm{M}=\mathrm{Sn}^{4+}, \mathrm{Ge}^{4+}\right.$ and $\left.\mathrm{Si}^{4+}\right)$. (b) Total and bulk conductivity of $\mathrm{Li}_{10} \mathrm{SnP}_{2} \mathrm{~S}_{12}$ and $\mathrm{Li}_{11} \mathrm{Si}_{2} \mathrm{PS}_{12}$ as extracted from impedance spectroscopy measurements. For comparison, the dashed dotted line represents the conductivity of the best oxide solid electrolyte, $\mathrm{Li}_{7} \mathrm{La}_{3} \mathrm{Zr}_{2} \mathrm{O}_{12}$ [44].

\section{5. $\mathrm{Li}_{2} \mathrm{~S}-\mathrm{P}_{2} \mathrm{~S}_{5}-\mathrm{Li}_{a} \mathrm{X}_{b}$ systems (mixed-anion effect or mixed-former effect)}

Another effective way to increase conductivity of inorganic glassy electrolytes is to combine two different anion species, which was called "mixed-anion effect" [46] or "mixed-former effect" [47]. Besides, the additional $\mathrm{Li}_{a} \mathrm{X}_{b}$ salts are useful for enhancing conductivity of glasses because of the increase in lithium concentration and the decrease in activation energy for conduction. For instance, Mercier et al. [29] reported that lithium halides, $\mathrm{LiX}(\mathrm{X}=\mathrm{Cl}, \mathrm{Br}$, and I), can be used to improve the ionic conductivity of $\mathrm{Li}_{2} \mathrm{~S}-\mathrm{P}_{2} \mathrm{~S}_{5}$ glass with the ratio $\mathrm{Li}_{2} \mathrm{~S} / \mathrm{P}_{2} \mathrm{~S}_{5}=2$. For the doped glasses obtained with the same LiX halide content, the conductivity varied in direct proportion to the polarizability of the halides $\left(\sigma_{\mathrm{Lil}}>\sigma_{\mathrm{LiBr}}>\sigma_{\mathrm{LiCl}}\right)$. The highest value of $\sigma$ was obtained for the saturated glass (LiI 45\%). While Ujiie et al [48, 49] investigated that in the (100- 
$x)\left(0.7 \mathrm{Li}_{2} \mathrm{~S} \cdot 0.3 \mathrm{P}_{2} \mathrm{~S}_{5}\right) \cdot x \mathrm{LiI}$ and $(100-x)\left(0.8 \mathrm{Li}_{2} \mathrm{~S} \cdot 0.2 \mathrm{P}_{2} \mathrm{~S}_{5}\right) \cdot x$ LiI glass electrolytes, the conductivities of glasses increased with increasing the LiI content. The glass at $x=20$ showed the highest conductivity of $5.6 \times 10^{-4} \mathrm{~S} \mathrm{~cm}^{-1}$ for the former and $2.7 \times 10^{-3} \mathrm{~S} \mathrm{~cm}^{-1}$ at $x=5$ for the latter.
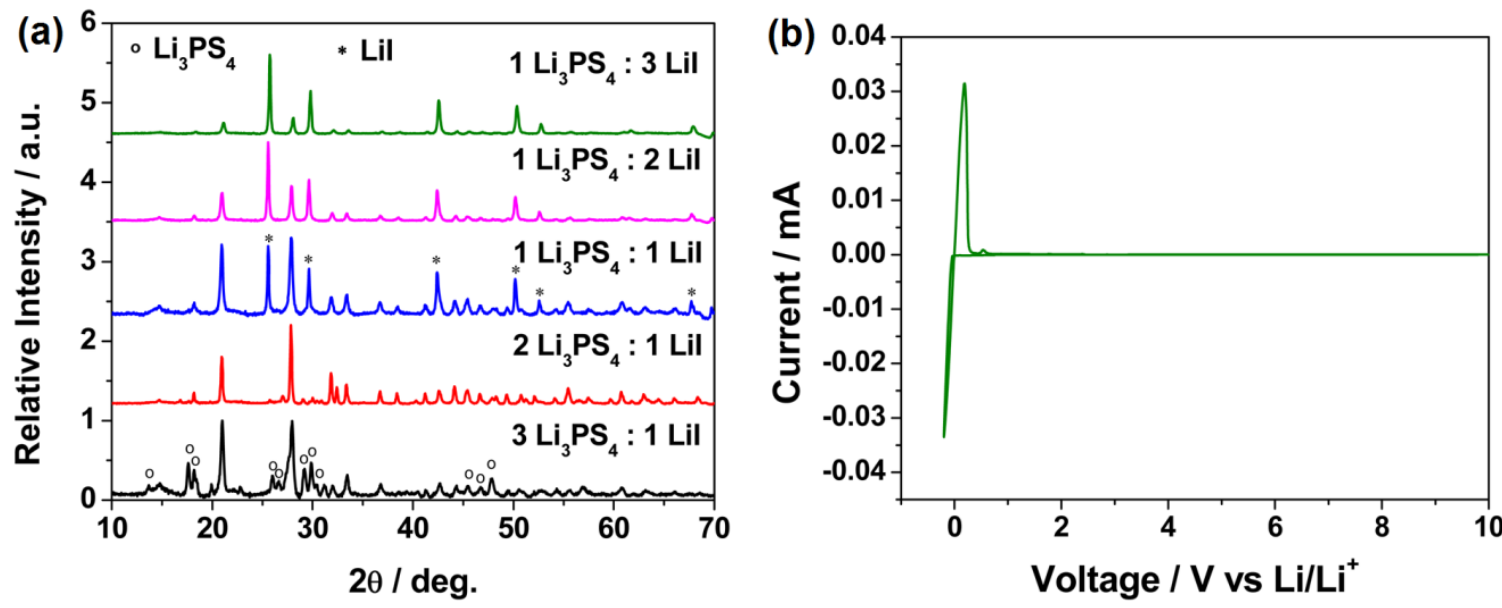

Fig. 12. (a) X-ray diffraction patterns of the $\mathrm{Li}_{3} \mathrm{PS}_{4} \cdot \mathrm{LiI}$ solid solution. Formation of a new phase at the 2:1 stoichiometric was observed from the XRD results. (b) Cyclic voltammogram for a $\mathrm{Li} / \mathrm{Li}_{7} \mathrm{P}_{2} \mathrm{~S}_{8} \mathrm{I} / \mathrm{Pt}$ cell at a scan rate of $1 \mathrm{mV} \mathrm{s}^{-1}$, demonstrating that the new electrolyte phase is stable up to $10 \mathrm{~V}$ vs. $\mathrm{Li} / \mathrm{Li}^{+}$.

Most recently, an iodide-based $\mathrm{Li}_{7} \mathrm{P}_{2} \mathrm{~S}_{8} \mathrm{I}$ superionic conductor was fabricated by mixing LiI and $\mathrm{Li}_{3} \mathrm{PS}_{4}$ with subsequent heat treatment [50]. Fig. 12a illustrates the XRD patterns of the samples with different $\mathrm{Li}_{3} \mathrm{PS}_{4} / \mathrm{LiI}$ ratios, from which a new phase was observed at a 2:1 ratio of $\mathrm{Li}_{3} \mathrm{PS}_{4} / \mathrm{LiI}$, with no reflections from the precursors. Therefore, the singular phase was formed according to the following reaction: $2 \mathrm{Li}_{3} \mathrm{PS}_{4}+\mathrm{LiI} \rightarrow \mathrm{Li}_{7} \mathrm{P}_{2} \mathrm{~S}_{8} \mathrm{I}$. Although relatively low ionic conductivity of $6.3 \times 10^{-4} \mathrm{~S} \mathrm{~cm}^{-1}$ was obtained, $\mathrm{Li}_{7} \mathrm{P}_{2} \mathrm{~S}_{8} \mathrm{I}$ shows an extremely high electrochemical stability up to $10 \mathrm{~V}$ vs. $\mathrm{Li}^{2} \mathrm{Li}^{+}$(Fig. 12b), which suggests that the presence of I enhances the 
stability of the sulfide electrolyte with metallic Li anode while demonstrating low charge-transfer resistance.

Another example for the "mixed-anion effect" is to introduce $\mathrm{O}^{2-}$ anions into the sulfide electrolytes. It was reported that the sulfide-based electrolytes had low chemical stability to moisture in air. Hydrolyses of these electrolytes caused structural change and generated $\mathrm{H}_{2} \mathrm{~S}$ gas [51].Therefore, handling of the sulfide solid electrolytes is restricted in an inert gas atmosphere. Howerver, Ohtomo et al [52] suggested that partial replacement $\mathrm{Li}_{2} \mathrm{~S}$ by $\mathrm{Li}_{2} \mathrm{O}$ in the $70 \mathrm{Li}_{2} \mathrm{~S} \cdot 30 \mathrm{P}_{2} \mathrm{~S}_{5}$ glass was effective in suppressing $\mathrm{H}_{2} \mathrm{~S}$ gas generation. Hayashi et al. [53] also reported that partial substitution of $\mathrm{P}_{2} \mathrm{O}_{5}$ for $\mathrm{P}_{2} \mathrm{~S}_{5}$ decreased the rate of $\mathrm{H}_{2} \mathrm{~S}$ generation from glass exposed to air. Unfortunately, in the oxysulfide glasses, the ionic conductivity decreased monotonically with increasing of $\mathrm{O}^{2-}$ content, while the activation energy increased. The formation of oxysulfide units and $\mathrm{PO}_{4}$ units with non-bridging oxygens, which act as a strong trap for $\mathrm{Li}^{+}$ion conduction, were expected to be responsible for the decrease in conductivity. Similar trend were also found by Trevey [54] and Ohtomo [55] et al in the $\mathrm{Li}_{2} \mathrm{~S} \cdot \mathrm{Li}_{2} \mathrm{O} \cdot \mathrm{P}_{2} \mathrm{~S}_{5}$ system electrolyte. An alternative approach to reduce $\mathrm{H}_{2} \mathrm{~S}$ generation is the addition of metal oxides, such as $\mathrm{CuO}, \mathrm{Fe}_{2} \mathrm{O}_{3}, \mathrm{ZnO}$, and $\mathrm{Bi}_{2} \mathrm{O}_{3}[56,57]$, which play a role in absorbing $\mathrm{H}_{2} \mathrm{~S}$ or bringing about acid-base reaction with $\mathrm{H}_{2} \mathrm{~S}$. Metal oxides have a largely negative value of Gibbs energy change $(\Delta \mathrm{G})$ for the following reaction: $\mathrm{M}_{x} \mathrm{O}_{y}+\mathrm{H}_{2} \mathrm{~S} \rightarrow \mathrm{M}_{x} \mathrm{~S}_{y}+\mathrm{H}_{2} \mathrm{O}$. The ball-milled $75 \mathrm{Li}_{2} \mathrm{~S} \cdot 25 \mathrm{P}_{2} \mathrm{~S}_{5}$ glass composites with one of the metal oxides effectively suppressed the $\mathrm{H}_{2} \mathrm{~S}$ gas generation after the storage of the composites in air. On the other hand, the $75 \mathrm{Li}_{2} \mathrm{~S} \cdot 25 \mathrm{P}_{2} \mathrm{~S}_{5}$ glass did not generate $\mathrm{H}_{2} \mathrm{~S}$ gas under $\mathrm{O}_{2}$ or $\mathrm{N}_{2}$ gas flow with low humidity, suggesting that the sulfide glass has a good chemical stability in dry air atmosphere.

\section{Other modification for $\mathrm{Li}_{2} \mathrm{~S}-\mathrm{P}_{2} \mathrm{~S}_{5}$ electrolyte}


Except for the aforementioned approaches, some other additives were also used in the $\mathrm{Li}_{2} \mathrm{~S}-\mathrm{P}_{2} \mathrm{~S}_{5}$ system in order to increase the ionic conductivity. For example, Zhang et al [58] reported that the coformer sulfide glasses of the $0.33\left[(1-y) \mathrm{B}_{2} \mathrm{~S}_{3} \cdot y \mathrm{P}_{2} \mathrm{~S}_{5}\right]-0.67 \mathrm{Li}_{2} \mathrm{~S}$ system generally exhibited higher $\mathrm{Li}^{+}$ionic conductivities than those of the single sulfide network former glasses; the room temperature conductivity of the glass with $y=0.3$ reached the highest value of $0.141 \mathrm{mS} \mathrm{cm}^{-1}$. While Yamauchi et al [59] suggested that addition of $\mathrm{LiBH}_{4}$ in the structure helped to improve the conductivity of $(100-x)\left(0.75 \mathrm{Li}_{2} \mathrm{~S} \cdot 0.25 \mathrm{P}_{2} \mathrm{~S}_{5}\right) \cdot x \mathrm{LiBH}_{4}$ glass electrolyte, and the glass at the composition of $x=33$ showed the highest Li-ion conductivity of $1.6 \times 10^{-3} \mathrm{~S} \mathrm{~cm}^{-1}$ at room temperature with a wide electrochemical window of up to $5 \mathrm{~V} \mathrm{vs}$. $\mathrm{Li} / \mathrm{Li}^{+}$.

Not only conductivity of solid electrolytes but also minimization of high resistance at the electrode/solid electrolyte interface and optimum solid-state battery fabrication are crucial for the development of high power all-solid-state lithium batteries. Formation of favorable contacts at electrode/electrolyte solid-solid interfaces is a key to improve electrochemical performance of all-solid-state batteries because charge-transfer reaction proceeds only at the contact interfaces. Several approaches such as ball milling process, pulsed laser deposition (PLD) technique ect. have been explored as effective routes [25-26, 60-61]. The electrode/solid electrolyte interface formation and solid-state battery fabrication, however, are not discussed here since they are beyond the topic of this review.

\section{Conclusions}

Sulfide-based ionic conductors are of major interest for all-solid-state Li-ion batteries. The review of sulfide electrolytes shows that the conductivity varies with different structures. Crystallization of the $\mathrm{Li}_{2} \mathrm{~S}-\mathrm{P}_{2} \mathrm{~S}_{5}$ glassy electrolyte increased the conductivity by 2 orders of 
magnitude below $360{ }^{\circ} \mathrm{C}$, while the conductivity decreased by heating of the $\mathrm{Li}_{2} \mathrm{~S}-\mathrm{P}_{2} \mathrm{~S}_{5}$ glass over $550{ }^{\circ} \mathrm{C}$ due to the formation of lower conductivity phase, such as $\mathrm{Li}_{4} \mathrm{P}_{2} \mathrm{~S}_{6}$. Thio-LISICON type $\mathrm{Li}_{7} \mathrm{P}_{3} \mathrm{~S}_{11}, \mathrm{Li}_{10} \mathrm{GeP}_{2} \mathrm{~S}_{12}$ and $\mathrm{Li}_{11} \mathrm{Si}_{2} \mathrm{PS}_{12}$ exhibited extremely high Li-ion conductivity over $10^{-2} \mathrm{~S}$ $\mathrm{cm}^{-1}$ at room temperature due to their body-centred cubic (bcc) anion sublattice and unique lithium-ion diffusion pathway. Anion substitution in the crystal structure (so-called "mixed-anion effect") is also an effective way to modify the energy landscape as well as the ionic conductivity. For example, introduction of $\mathrm{I}^{-}$in the $\mathrm{Li}_{2} \mathrm{~S} \cdot \mathrm{P}_{2} \mathrm{~S}_{5}$ glass increases the conductivity of sulfide electrolyte, whereas partial replacement of $\mathrm{S}^{2-}$ by $\mathrm{O}^{2-}$ decreases the conductivity although the $\mathrm{H}_{2} \mathrm{~S}$ generation from glass exposed to humid air was suppressed.

\section{Acknowledgments}

The authors would like to acknowledge the support from the U.S. Department of Energy under BMR program (with Lawrence Berkeley National Laboratory). 


\section{References}

[1]. S. Sawa, S. Okada, A. Yoshino, J. Power Sources 97-98 (2001) 430.

[2]. R. Ruffo, R. A. Huggins, C. M. Mari, M. Piana, W. Weppner, Ionics 11 (2005) 213.

[3] J. B. Goodenough and Y. Kim, Chem. Mater., 22 (2010) 587.

[4]. K. Xu, Chem. Rev., 104 (2004) 4303.

[5] C. Julien and G. A. Nazri, Solid State Batteries: Materials Design and Optimization, Kluwer Academic Publishers, Boston (1994).

[6] T. Minami, M. Tatsumisago, M. Wakihara, C. Iwakura, S. Kohjiya and I.I. Tanaka, Solid State Ionics for Batteries, Springer-Verlag, Tokyo (2005).

[7] U. V. Alpen, A. Rabenau, G. H. Talat, Appl. Phys. Lett., 30 (1977) 621.

[8] T. Lapp, S. Skaarup, A. Hooper, Solid State Ionics 11 (1983) 97.

[9] H. Aono, E. Sugimono, Y. Sadaoka, N. Imanaka and G. Adachi, J. Electrochem. Soc., 137 (1990) 1023.

[10] P. G. Bruce, A. R. West, J. Electrochem. Soc., 130 (1983) 662.

[11] Y. Inaguma, C. Liquan, M. Itoh, T. Nakamura, T. Uchida, H. Ikuta, M. Wakihara, Solid State Commun., 86 (1993) 689.

[12] R. Murugan, V. Thangadurai, and W. Weppner, Angew. Chem. Int. Ed., 46 (2007) 7778.

[13] A. Hayashi, S. Hama, H. Morimoto, T. Minami, M. Tatsumisago, J. Am. Ceram. Soc., 84 (2001) 477 .

[14] F. Mizuno, A. Hayashi, K. Tadanaga, and M. Tatsumisago, Adv. Mater., 17 (2005) 918.

[15] P. Knauth, Solid State Ionics, 180 (2009) 911.

[16] J. B. Bates, G. R. Gruzalski, N. J. Dudney, C. F. Luck, X. Yu, Solid State Ionics, 70/71 (1994) 619. 
[17] N. J. Dudney, Mater. Sci. Eng. B, 116 (2005) 245.

[18] J. Li, C. Ma, M. Chi, C. Liang, and N. Dudney, Adv. Energy Mater., 5 (2015) DOI: $10.1002 /$ aenm.201401408

[19] E. Quartarone and P. Mustarelli, Chem. Soc. Rev., 40 (2011) 2525.

[20] J. B. Goodenough and P. Singh. J. Electrochem. Soc., 162 (2015) A 2387.

[21] J. G. Kim, B. Son, S. Mukherjee, N. Schuppert, A. Bates, O. Kwon, M. J. Choi, H. Y. Chung, S. Park, J. Power Sources, 282 (2015) 299.

[22] N. Anantharamulu, K. K. Rao, G. Rambabu, B. V. Kumar, V. Radha, M. Vithal, J. Mater. Sci., 46 (2011) 2821.

[23] S. Teng, J. Tan, A. Tiwari, Curr. Opin. Solid State Mater. Sci. 18 (2014) 29.

[24] V. Thangadurai, S. Narayanan and D. Pinzaru, Chem. Soc. Rev., 43 (2014) 4714.

[25] S. S. Berbano, M. Mirsaneh, M. T. Lanagan, and C. A. Randall, Int. J. Appl. Glass Sci., 4 (2013) 414.

[26] M. Tatsumisago. M. Nagao, A. Hayashi, J. Asian Ceram. Soc., 1 (2013) 17.

[27] R. Kanno and M. Murayama, J. Electrochem. Soc., 148 (2001) A742.

[28] A. R. West, Basic Solid State Chemistry, (1999) 2nd ed., Chap. 7.5, p. 321, John Wiley \& Sons, Chichester, U.K.

[29] R. Mercier, J.-P. Malugani, B. Fahys, G. Robert, Solid State Ionics, 5 (1981) 663.

[30] A. Hayashi, K. Minami, S. Ujiie, M. Tatsumisago, J. Non-Cryst. Solids, 356 (2010) 2670.

[31] A. Pradel, M. Ribes, Solid State Ionics, 18-19 (1986) 351.

[32] M. Tatsumisago, Solid State Ionics, 175 (2004) 13.

[33] Y. Seino, T. Ota, K. Takada, A. Hayashi, and M. Tatsumisago, Energy Environ. Sci., 7 (2014) 627.

[34] F. Mizuno, A. Hayashi, K. Tadanaga, M. Tatsumisago, Solid State Ionics, 177 (2006) 2721. 
[35] M. Tachez, J.-P. Malugani, R. Mercier, G. Robert, Solid State Ionics, 14 (1984) 181.

[36] Z. Liu, W. Fu, E. A. Payzant, X. Yu, Z. Wu, N. J. Dudney, J. Kiggans, K. Hong, A. J. Rondinone, and C. Liang, J. Am. Chem. Soc., 135 (2013) 975.

[37] T. Minami, N. Machida, Mater. Sci. Eng. B, 13 (1992) 203.

[38] T. K. Pietrzak, J. E. Garbarczyk, I. Gorzkowska, M. Wasiucionek, J. L. Nowinski, S.

Gierlotka, P. Jozwiak, J. Power Sources, 194 (2009) 73.

[39] R. Kanno, T. Hata, Y. Kawamoto, M. Irie, Solid State Ionics, 130 (2000) 97.

[40] N. Kamaya, K. Homma, Y. Yamakawa, M. Hirayama, R. Kanno, M. Yonemura, T. Kamiyama, Y. Kato, S. Hama, K. Kawamoto and A. Mitsui, Nat. Mater. 10 (2011) 682.

[41] Y. Wang, W. D. Richards, S. P. Ong, L. J. Miara, J. C. Kim, Y. Mo and G. Ceder, Nat. Mater., 14 (2015) 1026.

[42] Y. Mo, S. P. Ong, and G. Ceder, Chem. Mater., 24 (2012) 15.

[43] P. Bron, S. Johansson, K. Zick, J. S. Gunne, S. Dehnen, and B. Roling, J. Am. Chem. Soc., $135(2013) 15694$.

[44] A. Kuhn, O. Gerbig, C. Zhu, F. Falkenberg, J. Maier and B. V. Lotsch. Phys. Chem. Chem. Phys., 16 (2014) 14669.

[45] S. P. Ong, Y. Mo, W. D. Richards, L. Miara, H. S. Lee, and G. Ceder, Energy Environ. Sci., $6(2013) 148$.

[46] M. Tatsumisago, N. Machida and T. Minami, J. Ceram. Soc. Jpn., 95 (1987) 197.

[47] B. Raguenet, G. Tricot, G. Silly, M. Ribes, A. Pradel, Solid State Ionics, 208 (2012) 25.

[48] S. Ujiie, A. Hayashi, M. Tatsumisago, Solid State Ionics, 211 (2012) 42.

[49] S. Ujiie, A. Hayashi, M. Tatsumisago, J. Solid State Electrochem., 17 (2013) 675.

[50] E. Rangasamy, Z. Liu, M. Gobet, K. Pilar, G. Sahu, W. Zhou, H. Wu,S. Greenbaum, and C. Liang, J. Am. Chem. Soc., 137 (2015) 1384. 
[51] H. Muramatsu, A. Hayashi, T. Ohtomo, S. Hama, M. Tatsumisago, Solid State Ionics 182 (2011) 116 .

[52] Takamasa Ohtomo, Akitoshi Hayashi, Masahiro Tatsumisago, Koji Kawamoto, J. Non-Cryst. Solids, 364 (2013) 57.

[53] A. Hayashi, H. Muramatsu, T. Ohtomo, S. Hama, M. Tatsumisago, J. Alloy. Compd., 591 (2014) 247.

[54] J. E. Trevey, J. R. Gilsdorf, S. W. Miller, S.-H. Lee, Solid State Ionics 214 (2012) 25.

[55] T. Ohtomo, A. Hayashi, M. Tatsumisago, K. Kawamoto, J. Solid State Electrochem., 17 (2013) 2551.

[56] T. Ohtomo, A. Hayashi, M. Tatsumisago, K. Kawamoto, J. Mater. Sci., 48 (2013) 4137.

[57] A. Hayashi, H. Muramatsu, T. Ohtomo, S. Hama and M. Tatsumisago, J. Mater. Chem. A., 1 (2013) 6320 .

[58] Z. Zhang and J. H. Kennedy, Solid State Ionics, 38 (1990) 217.

[59] A. Yamauchi, A. Sakuda, A. Hayashi, M. Tatsumisago, J. Power Sources, 244 (2013) 707.

[60] A. Hayashi, Y. Nishio, H. Kitaura, M. Tatsumisago, Electrochem. Commun., 10 (2008) 1860.

[61] A. Sakuda, A. Hayashi, T. Ohtomo, S. Hama and M. Tatsumisago, J. Power Sources, 196 (2011) 6735 . 


\section{Graphical Abstract}

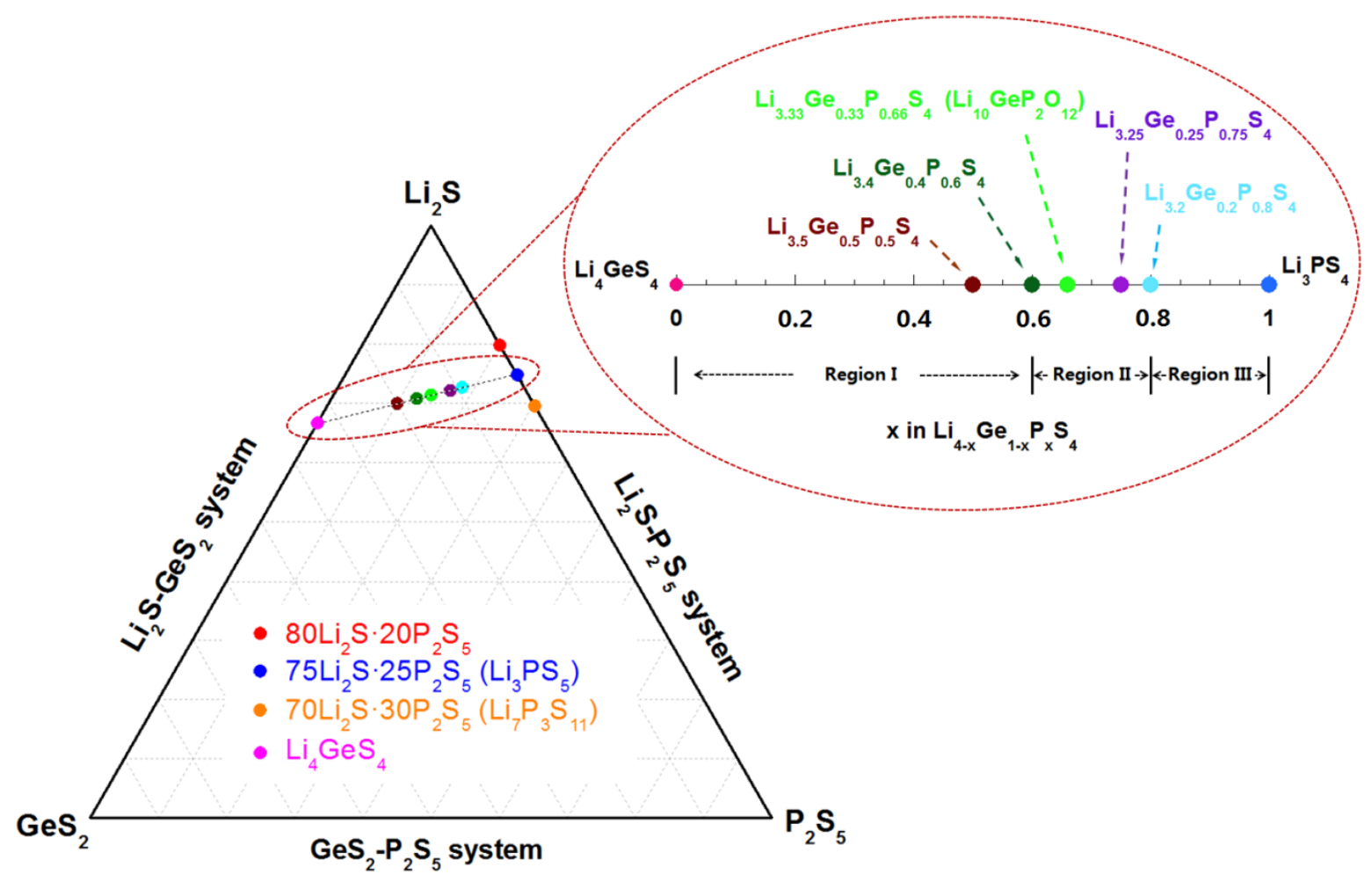

$\mathrm{Li}_{2} \mathrm{~S}-\mathrm{GeS}_{2}-\mathrm{P}_{2} \mathrm{~S}_{5}$ ternary diagram showing various sulphide compounds as solid electrolytes for Li-ion batteries 